\title{
Analysis of $\mathrm{BH} 3-0 n l y$ proteins upregulated in response to oxygen/glucose deprivation in cortical neurons identifies Bmf but not Noxa as potential mediator of neuronal injury
}

\author{
S Pfeiffer ${ }^{1}$, U Anilkumar ${ }^{1}$, G Chen ${ }^{1}$, S Ramírez-Peinado ${ }^{2,3}$, J Galindo-Moreno ${ }^{2}$, C Muñoz-Pinedo ${ }^{2}$ and JH M Prehn ${ }^{\star, 1}$
}

Stress signaling in response to oxygen/glucose deprivation (OGD) and ischemic injury activates a group of pro-apoptotic genes, the $\mathrm{Bcl}-2$ homology domain 3 (BH3)-only proteins, which are capable of activating the mitochondrial apoptosis pathway. Targeted studies previously identified the BH3-only proteins Puma, Bim and Bid to have a role in ischemic/hypoxic neuronal injury. We here investigated the transcriptional activation of pro-apoptotic BH3-only proteins after OGD-induced injury in murine neocortical neurons. We observed a potent and early upregulation of noxa at mRNA and protein level, and a significant increase in Bmf protein levels during OGD in neocortical neurons and in the ipsilateral cortex of mice subjected to transient middle cerebral artery occlusion (tMCAO). Surprisingly, gene deficiency in noxa reduced neither OGD- nor glutamate-induced neuronal injury in cortical neurons and failed to influence infarct size or neurological deficits after tMCAO. In contrast, bmf deficiency induced significant protection against OGD- or glutamate-induced injury in cultured neurons, and bmf-deficient mice showed reduced neurological deficits after tMCAO in vivo. Collectively, our data not only point to a role of Bmf as a BH3-only protein contributing to excitotoxic and ischemic neuronal injury but also demonstrate that the early and potent induction of noxa does not influence ischemic neuronal injury.

Cell Death and Disease (2014) 5, e1456; doi:10.1038/cddis.2014.426; published online 9 October 2014

Cerebral ischemia, resulting from occlusion or hemorrhaging of blood vessels supplying the brain, triggers a complex series of physiological, biochemical and gene expression changes ultimately mediating neuronal injury and activation of cell death mechanisms. ${ }^{1}$ Outside of the damaged necrotic infarct core following focal cerebral ischemia, the ischemic penumbra presents an area of less severe neuronal injury, functionally impaired but structurally intact, with active cell death pathways contributing to neuronal injury and loss of neurological function over time. ${ }^{2}$ Among pro-inflammatory and other processes, progressive neuronal injury of the ischemic penumbra is associated with glutamate-induced depolarization, energetic stress and activation of AMP-activated protein kinase (AMPK), with the later triggering both pro-survival and pro-apoptotic signaling in neurons. ${ }^{3,4}$

Mitochondrial-mediated apoptosis has been shown to be involved in neuronal cell death after cerebral ischemia in studies of both patient samples and animal models of acute stroke, ${ }^{5}$ with reduced expression of anti-apoptotic $\mathrm{Bcl}-2$ and $\mathrm{Bcl}-\mathrm{w}$ and induction of pro-apoptotic Bax observed within the ischemic core and surrounding penumbra. ${ }^{6}$ Translocation of cytosolic Bax to the mitochondrial outer membrane is key for the activation of mitochondrial apoptosis in neurons. ${ }^{7-11}$ This process is inhibited by anti-apoptotic Bcl-2 family proteins, ${ }^{12-15}$ and overexpression of anti-apoptotic Bcl-2 family proteins have demonstrated in vivo neuroprotective roles against ischemic neuronal cell death. ${ }^{15-17}$ Bax translocation and membrane insertion eventually results in mitochondrial membrane permeabilization and the release of cytochrome $c$ and other pro-apoptotic proteins that trigger caspase-dependent and -independent cell death processes. ${ }^{18,19}$ Bax activation is triggered by the transcriptional and posttranslational activation of Bcl-2 homology domain 3 (BH3)-only proteins that directly activate Bax and/ or indirectly activate Bax by neutralizing the activity of antiapoptotic Bcl-2 family proteins ('de-repression'). ${ }^{19-21}$

A role for several BH3-only proteins, in particular Bid. ${ }^{22,23}$ and Puma, ${ }^{24}$ in ischemic neuronal injury has been previously suggested in studies using animals deficient in these genes. Among the pro-apoptotic BH3-only proteins implicated in ischemic neuronal cell death, the roles of Bcl-2-modifying factor (Bmf) and Noxa remain poorly investigated. ${ }^{25}$ Both are known to act as indirect activators of apoptosis with roles as 'de-repressors', preventing sequestration of direct activators

\footnotetext{
${ }^{1}$ Department of Physiology and Medical Physics, Royal College of Surgeons in Ireland, 123 St. Stephen's Green, Dublin 2, Ireland and ${ }^{2}$ Cell Death Regulation Group, IDIBELL (Bellvitge Biomedical Research Institute), Gran Via de L'Hospitalet 199, Barcelona 08908, Spain

${ }^{*}$ Corresponding author: JHM Prehn, Department of Physiology and Medical Physics and RCSI Neuroscience Research Centre, Centre for the Study of Neurological Disorders, Royal College of Surgeons in Ireland, 123 St. Stephen's Green, Dublin 2, Ireland. Tel: +353 1402 2255; Fax: +353 1 402 2447; E-mail: prehn@ @rsi.ie ${ }^{3}$ Current address: BioMedX GmbH, Im Neuenheimer Feld 583, Heidelberg 69120, Germany.

Abbreviations: AMPK, AMP-activated protein kinase; BH3, Bcl-2 homology domain 3; Bmf, Bcl-2-modifying factor; DIV, days in vitro; eGFP, enhanced green fluorescent protein; NMDA, N-methyl-D-aspartate; OGD, oxygen/glucose deprivation; PCA, posterior cerebral artery; PcomA, posterior communicating artery; qPCR, quantitative PCR; SCA, superior cerebellar artery; tMCAO, transient middle cerebral artery occlusion; WT, wild type

Received 02.5.14; revised 28.8.14; accepted 04.9.14; Edited by M Agostini
} 
such as Puma, Bid and Bim by pro-survival Bcl-2 family with limited effect on cytochrome $c$ release in cellular and isolated mitochondrial studies. ${ }^{20,26,27} \mathrm{Bmf}$ has been reported to have roles in cell death in response to anoikis through the inhibition of Bcl-2 ${ }^{28,29}$ and has been shown to be induced under conditions of hypoxia and through $\mathrm{c}$-jun $\mathrm{N}$-terminal kinase (JNK) and AMPK activation in response to bioenergetic stress, ${ }^{30,31}$ as well as having roles in autophagy and in cell death induced by inhibition of glucose metabolism. ${ }^{32-34}$ Noxa was originally described as a primary p53-response gene and mediator of p53-dependent apoptosis ${ }^{27}$ but can also be transcriptionally induced during ischemia through hypoxia-inducible factor (HIF)-1alpha, ${ }^{35}$ JNK and AMPK activation. $^{27,36}$ This study investigated whether noxa and bmf are induced in response to oxygen/glucose deprivation (OGD) in cultured cortical neurons in vitro and in a mouse model of transient focal ischemic injury in vivo and investigates the role of these pro-apoptotic genes in mediating neuronal injury in vitro and in vivo.

\section{Results}

Levels of noxa mRNA are increased following OGD in primary cortical neurons. In order to identify which pro-apoptotic BH3-only proteins may have a role in ischemic neuronal injury, cultures of neocortical neurons were subjected to OGD in vitro. Mature cultures of neocortical neurons were subjected to $45 \mathrm{~min}$ of OGD and allowed to recover under normoxic conditions for various timepoints $(4,6,24 \mathrm{~h})$ at which points mRNA levels of BH3-only proteins were assessed by real-time quantitative PCR (qPCR) analysis. mRNA levels for noxa were found to be upregulated from $4 \mathrm{~h}$ onward, and levels were maintained significantly up to $24 \mathrm{~h}$ at 3.9-fold (Figure 1a). Other markers investigated, including bim and puma (Figures 1b-d), showed no significant change when compared with controls. We also observed a delayed, 2.3-fold over-representation in bmf expression $24 \mathrm{~h}$ after OGD; however, this was not within the range of statistical significance.

noxa and bmf mRNA changes following transient focal cerebral ischemia. Following the data obtained in vitro from neocortical neurons, we attempted to validate these results in vivo in a mouse model of transient focal ischemia. Wildtype (WT) mice were sham-treated or subjected to $60 \mathrm{~min}$ ischemia by occlusion of the middle cerebral artery (MCA) followed by reperfusion for 3,8 and $24 \mathrm{~h}$, at which time points mice were euthanized and brains were removed for gene expression analysis to determine the expression of noxa and bmf mRNA in the ipsilateral and contralateral cortex. Realtime qPCR analysis determined that noxa mRNA expression was significantly increased 2.7-fold in the ipsilateral cortex of animals $3 \mathrm{~h}$ following reperfusion and maintained a 2.1 - and 1.4-fold increase at 8 and $24 \mathrm{~h}$, respectively, returning towards baseline (Figure 2a), compared with ipsilateral cortices of sham-operated mice. Cortical expression of bmf mRNA was maintained at baseline, 3 and $8 \mathrm{~h}$ and increased 1.6 -fold at $24 \mathrm{~h}$ following reperfusion after MCA occlusion in
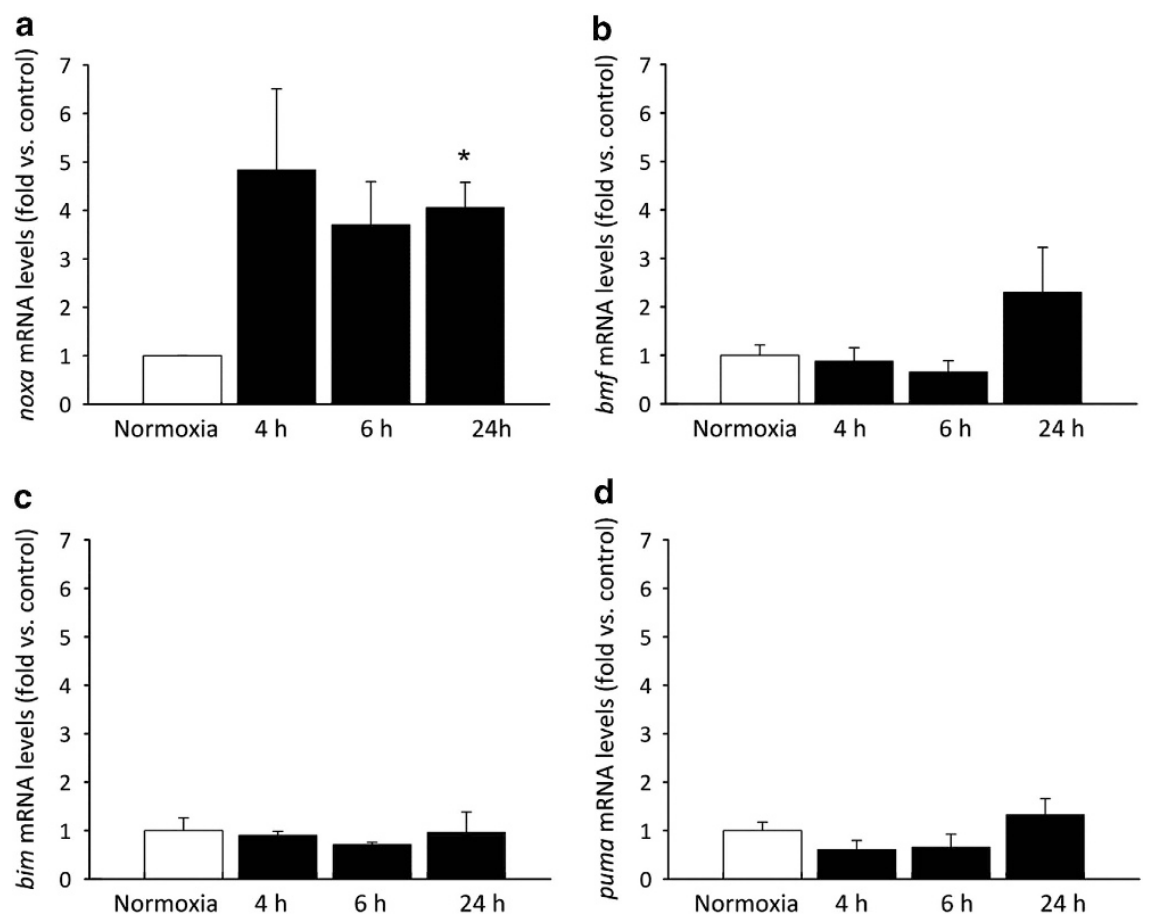

Figure 1 Induction of BH3-Only proteins in response to OGD in cortical neurons. Real-time qPCR analysis of mRNA expression of BH3-only proteins in cortical neurons subjected to $45 \mathrm{~min}$ OGD and allowed to recover under normoxic conditions for the times indicated. Controls were maintained under normoxic conditions. (a) mRNA levels for noxa were found to be upregulated from $4 \mathrm{~h}$, and levels were maintained significantly up to $24 \mathrm{~h}$. (b) bmf mRNA is not significantly induced by OGD. (c and d) Other markers investigated, bim and puma, respectively, showed no significant change when compared with control. Data were normalized to $\beta$-actin levels and expressed as relative to controls; presented as mean \pm S.E.M.; $n=3$ separate experiments carried out in triplicate. ${ }^{*} P<0.05$ compared with sham-treated control (ANOVA, post hoc Tukey's test) 

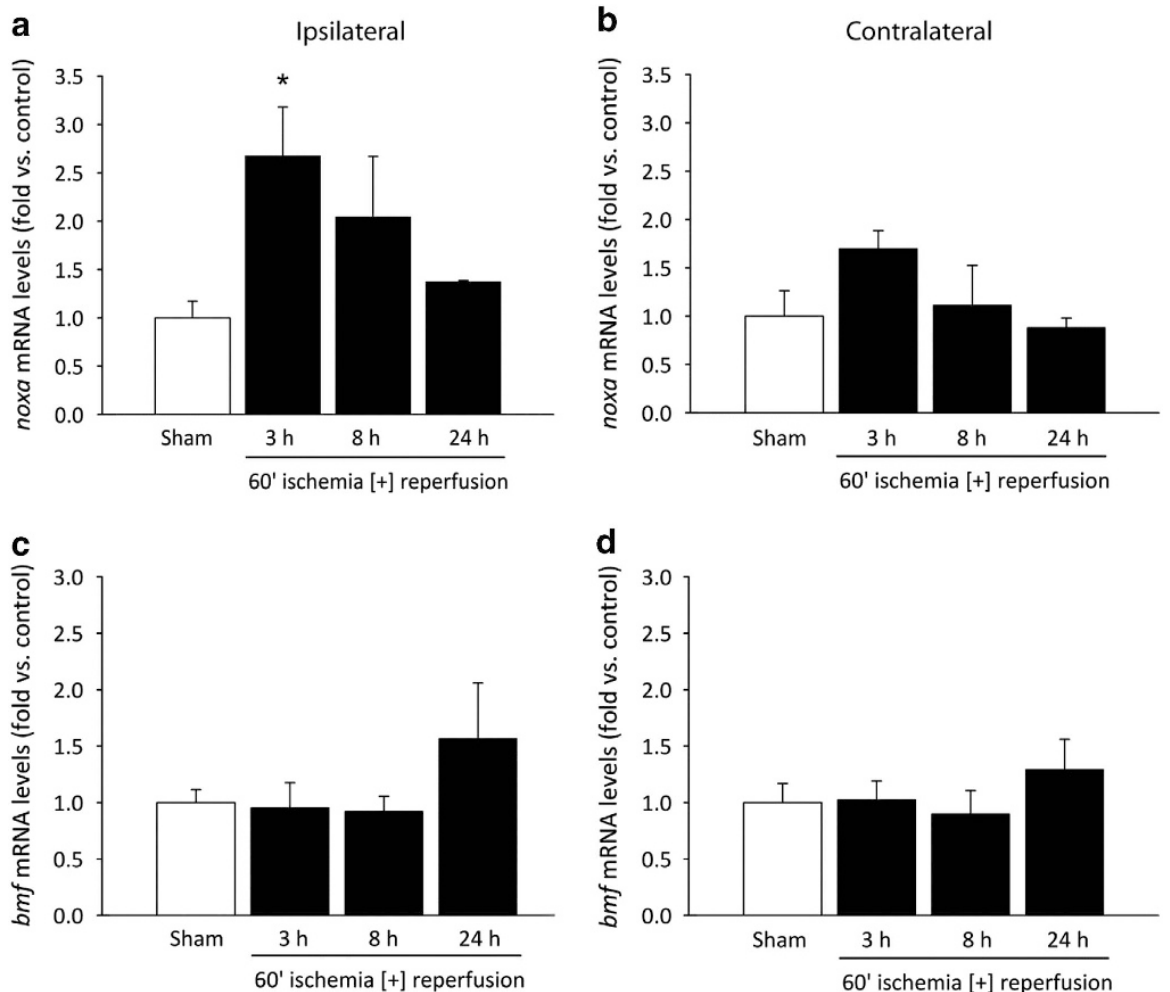

Figure 2 Induction of bmf and noxa following transient focal cerebral ischemia in wt mice. Real-time qPCR measurement of (a and $\mathbf{b})$ noxa and (c and $\mathbf{d})$ bmf mRNA expression in the cortex 3,8 and $24 \mathrm{~h}$ following $60 \mathrm{~min}$ MCA occlusion with reperfusion. Data were normalized to $\beta$-actin levels and fold increases expressed relative to matched controls for $n=3$ per group. ${ }^{*} P<0.05$ compared with sham-treated control (ANOVA, post hoc Tukey's test)

the ipsilateral cortex (Figure 2c) compared with shamoperated ipsilateral cortices, but again this did not reach the level of statistical significance. Contralateral cortical mRNA expression of mice subjected to transient middle cerebral artery occlusion (tMCAO) showed no significant difference to sham-operated contralateral cortices but tended to mirror the trends observed in the ipsilateral cortex (Figures $2 b$ and $d$ ), consistent with a progressive increase of intracranial pressure due to cerebral edema. These data confirm in vitro observations of early noxa induction after ischemic conditions, maintained up to $24 \mathrm{~h}$. In contrast, induction of bmf mRNA, similar to the OGD experiments, was not statistically significant following cerebral ischemia (Figure 2c).

Deletion of noxa does not confer protection to excitotoxic and OGD-induced neuronal injury in cultured primary cortical neurons. Early and significant induction of noxa mRNA observed both in vitro after OGD and in vivo in response to ischemia prompted investigation of Noxa protein induction and the effects of deletion of noxa in ischemic neuronal injury. Levels of Noxa were examined in WT primary cortical neurons after OGD treatment followed by recovery for $0,1,4,6$ and $24 \mathrm{~h}$ by western blotting. Controls were shamexposed and maintained under normoxic conditions. Fortyfive minutes of OGD in healthy primary cortical neurons was sufficient to induce a significant increased expression of Noxa protein from $\mathrm{O}$ after treatment and maintained significantly up to $24 \mathrm{~h}$ (Figure $3 \mathrm{a}$ ) compared with normoxic controls, consistent with the observed upregulation of noxa mRNA. As a positive control for OGD-induced neuronal injury, we observed a significant increase in the accumulation of caspase/calpain-mediated II-spectrin breakdown cleavage products $^{37-39}$ in cortical neurons after OGD (see below; Figure 5b).

In order to examine the effects of deletion of noxa in ischemic neuronal injury, cortical neurons derived from WT and noxa-deficient mice were sham-treated or subjected to either $45 \mathrm{~min}$ OGD or exposure to $\mathrm{N}$-methyl-D-aspartate (NMDA)/glycine $(100 \mu \mathrm{M} / 10 \mu \mathrm{M})$ for $5 \mathrm{~min}$ and allowed to recover under normoxic conditions for $24 \mathrm{~h}$. Controls were sham-exposed and maintained under normoxic conditions. Assessment of cell death $24 \mathrm{~h}$ after OGD treatment (Figure $3 \mathrm{~b}$ ) or NMDA treatment (Figure $3 \mathrm{c}$ ) by Hoechst and $\mathrm{PI}$ staining indicated no difference in the cell death levels in WT cortical neurons subjected to OGD $(56.82 \% \pm 1.22)$ or NMDA $(54.89 \% \pm 1.31)$ insult compared with noxa-deficient cortical neurons subjected to OGD $(59.17 \% \pm 3.62)$ or NMDA $(49.47 \% \pm 2.03)$, demonstrating that no significant protection is conferred with deletion of noxa in vitro.

noxa-deficient mice are not protected from ischemic injury in vivo. Next we sought to determine a role for Noxa in vivo by ischemic infarct assessment in WT compared with noxa-deficient mice subjected to transient focal cerebral ischemia. We confirmed no significant difference in age and weight of the mice at the time of experiment and observed no significant differences between genotypes in the plasticity of the posterior communicating artery (PcomA; see Methods). 
Assessment of infarct volume was made $24 \mathrm{~h}$ following 60 min MCA occlusion with reperfusion by Cresyl violet/Niss staining encompassing the cortex and striatum within the vascular territory of the MCA and expressed as a percentage of contralateral hemisphere to correct for differences in

a

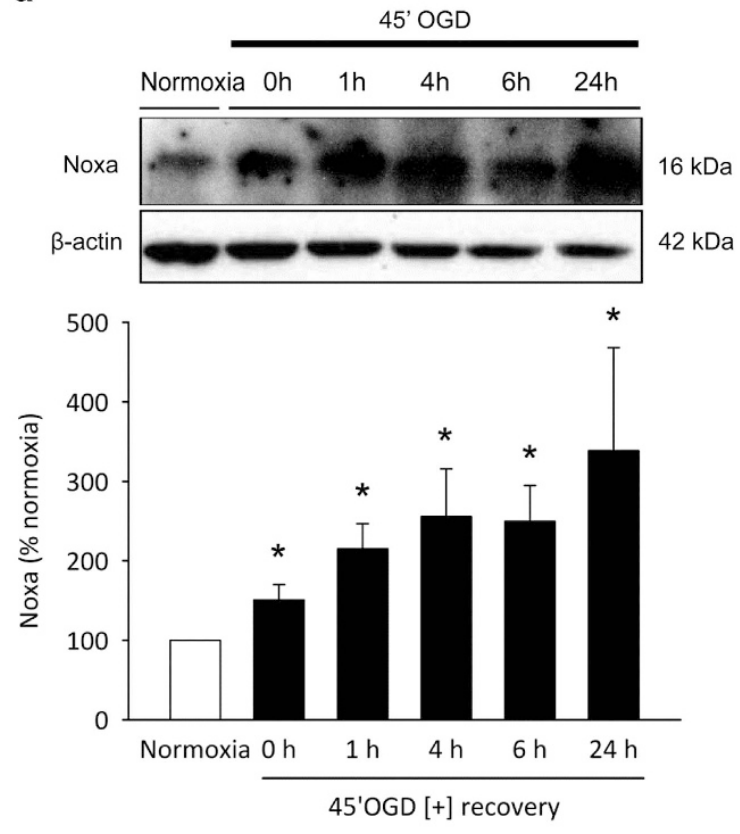

b

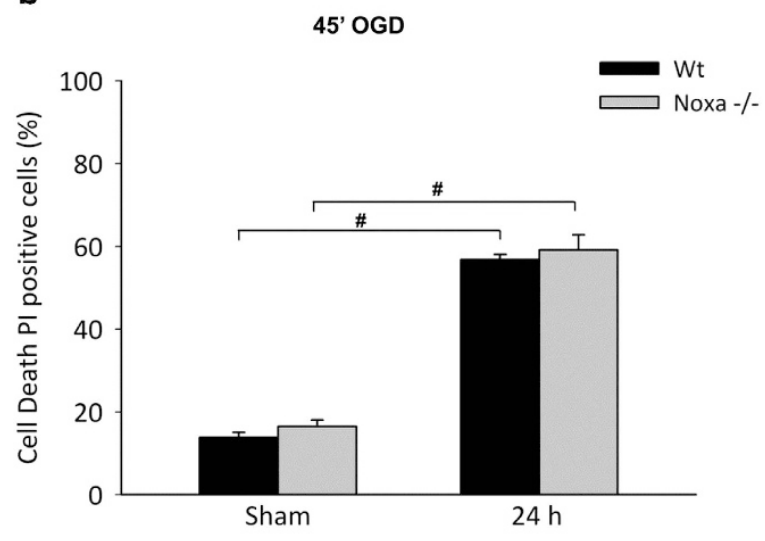

C

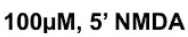

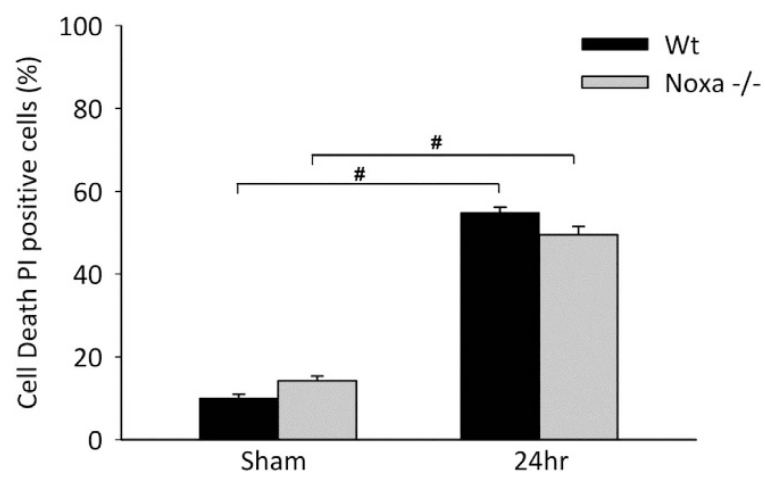

the brain size and brain edema. Mice deficient in noxa did not demonstrate any significant reduction in infarct volume (Figure $4 \mathrm{a}$ ), with an infarct volume of $37.2 \pm 2.2 \%$ compared with $29.0 \pm 1.7 \%$ in WT animals (Figures $4 a$ and b). Neurological deficit scores were also evaluated at $\mathrm{Oh}$ (Figure 4c) and $24 \mathrm{~h}$ (Figure 4d) following ischemia with reperfusion. There was no significant improvement in neurological deficits observed in noxa-deficient mice at either time point examined. Taken together, the above data demonstrate that the early induction of noxa may contribute to non-excitotoxic components of neuronal injury but has no influence neuronal survival after OGD in vitro or ischemic injury in vivo.

Bmf protein levels are increased following OGD in primary cortical neurons and focal cerebral ischemia in mice. To explore a possible increase in Bmf protein expression following ischemic neuronal injury, levels of Bmf were examined in primary cortical neurons after OGD treatment and in the ipsilateral cortex of WT mice subjected to $60 \mathrm{~min}$ ischemia followed by reperfusion for 3 and $24 \mathrm{~h}$ by western blotting. Forty-five minutes of OGD in healthy primary cortical neurons was sufficient to induce a significant increased expression of Bmf $24 \mathrm{~h}$ after treatment (Figure 5a). Expression of Bmf was also found to be significantly increased in the ipsilateral cortex of WT mice at $24 \mathrm{~h}$ following reperfusion after ischemia (Figure $5 \mathrm{c}$ ).

To confirm initiation of apoptotic cell death resulting from OGD or ischemia, quantitative western blotting analysis was also carried out for all-spectrin proteolysis. all-Spectrin proteolysis during apoptosis triggered by cerebral ischemia has been implicated in hypoxic-ischemic neuronal injury. ${ }^{37,40,41}$ Considerable evidence documenting the accumulation of caspase-3- and calpain-mediated all-spectrin breakdown products and corresponding decrease of fulllength all-spectrin protein after OGD in hippocampal slice cultures in vitro and in the ipsilateral cortex of rodents subjected to tMCAO injury in vivo provides substantial evidence supporting the use of all-spectrin breakdown as a

Figure 3 Induction of Noxa and effect of noxa deletion on neuronal injury primary cortical neurons. (a) Western blotting and densitometric analysis comparing the levels of Noxa induction in OGD-treated cortical neurons allowed to recover under normoxic conditions for the times indicated, confirming significant Noxa protein induction. Significant increases in Noxa induction were observed at $\mathrm{O}$ and maintained up to $24 \mathrm{~h}$ compared with normoxic controls. Data presented as mean \pm S.E.M. from $n=4$ independent experiments from $n=4$ independent cultures. ${ }^{*} P<0.05$ compared with sham-treated controls. ( $b$ and $\mathbf{c}$ ) Cortical neurons derived from WTand noxa-deficient mice were sham-treated or subjected to either $45 \mathrm{~min}$ OGD or a model of excitotoxic NMDA receptor overactivation by exposure to NMDA/glycine $(100 \mu \mathrm{M} / 10 \mu \mathrm{M})$ for $5 \mathrm{~min}$ and allowed to recover under normoxic conditions for $24 \mathrm{~h}$. Cell death was assessed after $24 \mathrm{~h}$ in each model by Hoechst and PI staining, and three subfields were captured per well, with a minimum of three wells analyzed per condition. Nuclei uniformly stained with Hoechst were counted as viable and condensed; PI-positive nuclei were scored as dead neurons and expressed as a percentage of the total population. Deficiency of noxa in cortical neurons neither reduced (b) OGD- or (c) glutamate-induced neuronal injury in cortical neurons. Data presented as mean \pm S.E.M., figures representative of $n=3$ independent experiments from $n=3$ independent cultures carried out in triplicate with similar results. ${ }^{*} P<0.05$ compared with sham-treated control; ${ }^{\#} P<0.05$ between treatments (ANOVA, post hoc Tukey's test) 
a

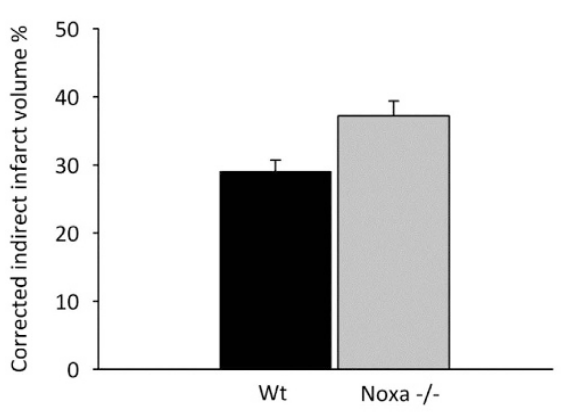

C

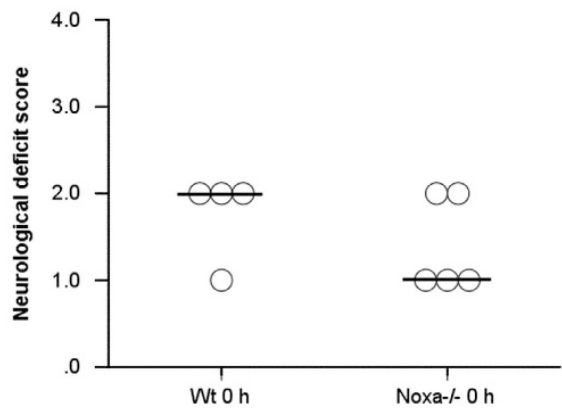

b

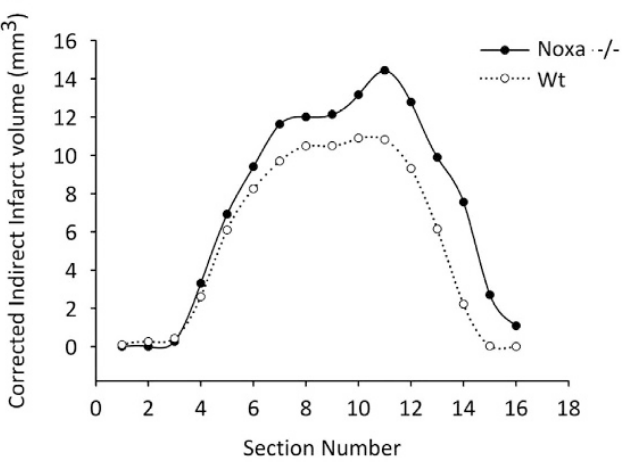

d

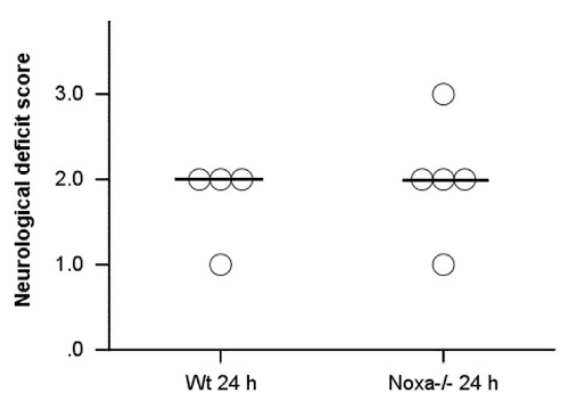

Figure 4 noxa-Deficiency confers no protection against ischemic injury. Infarct volume was assessed $24 \mathrm{~h}$ after focal cerebral ischemia by cresyl violet/Nissl staining. Infarct volume was calculated for direct infarct volume and corrected for edema of infarcted tissue for (a) total indirect infarct volume and (b) indirect infarct volume of each section. Mice deficient in noxa failed to influence infarct size compared with WT (Mann-Whitney $U$ test). Results were quantified and presented as a percentage of infarct volume compared with WT treated. (c and d) Neurological deficit scores after induction of tMCAO in WT and noxa-deficient mice at 0 and $24 \mathrm{~h}$ following 60 min ischemia with reperfusion. No differences in neurological scoring outcome were found between noxa-deficient compared with WT matched controls after $24 \mathrm{~h}$ reperfusion. Circles and bar represent deficit score and median score, respectively. Data are representative of $n \geq 4-5$ for each group WT and noxa-deficient mice

useful biomarker in models of focal ischemia. ${ }^{37-39}$ Western blotting analysis revealed a significantly increased accumulation of the $145 \mathrm{kDa}$ all-spectrin breakdown product both in vitro in cortical neurons (Figure $5 \mathrm{~b}$ ) and in vivo in the ischemic ipsilateral cortex (Figure $5 \mathrm{~d}$ ) at $24 \mathrm{~h}$, indicating the initiation of calpain/caspase-3-dependent apoptosis as a result of OGD and focal cerebral ischemia.

Cell death is attenuated in bmf-deficient primary cortical neuron cultures following OGD. We also examined the effect of gene deficiency of bmf in in vitro models of neuronal injury, by OGD and excitotoxic NMDA receptor overactivation in cortical neurons derived from WT and bmf-deficient mice. Assessment of cell death $24 \mathrm{~h}$ after OGD treatment (Figure 6a) or NMDA treatment (Figure 6b) by Hoechst and $\mathrm{PI}$ staining indicated significantly reduced cell death in bmfdeficient neurons subjected to OGD $(31.4 \pm 1.6 \%)$ or NMDA $(42.2 \pm 2.0 \%)$ insult compared with WT cortical neurons subjected to OGD $(45.2 \pm 1.0 \%)$ or NMDA $(56.3 \pm 1.15 \%)$, implicating bmf in the apoptotic response to both OGD and NMDA receptor overactivation. In both experiments, there was no difference in cell death between WT and bmf-deficient cells for sham-treated controls.

In order to demonstrate that overexpression of bmf would reverse the neuroprotective effect observed in bmf-deficient neurons, cortical neurons derived from WT mice were cotransfected with a vector expressing bmf and an enhanced green fluorescent protein (eGFP)-expressing vector and subjected to OGD. Assessment of cell death of eGFPpositive cells $24 \mathrm{~h}$ after OGD treatment (Figure $6 \mathrm{c}$ ) indicated that overexpression of bmf significantly exacerbated cell death when compared with control eGFP-transfected neurons.

bmf may contribute to ischemic neuronal injury in vivo. We then sought to examine the effect of bmf deletion in vivo, comparing infarct volume in WT mice to bmfdeficient mice after tMCAO. Again, no significant difference in age and weight of the mice at the time of experiment was confirmed, and plasticity of the PcomA was observed (see Methods). Assessment of infarct volume revealed mice deficient in bmf demonstrated no significant difference in infarct volume following tMCAO (Figures $7 a$ and b) when compared with WT. The infarct volume in bmf-deficient mice was $27.9 \pm 1.8 \%$ compared with $35.9 \pm 5.2 \%$ in WT mice; however, this did not reach the level of statistical significance.

Decreased neurological deficit scoring was also observed at $0 \mathrm{~h}$ (Figure 7c) and $24 \mathrm{~h}$ (Figure 7d) following ischemia with reperfusion, with bmf-deficient mice (Median (interquartile range), 1.5 (1.0)) showing improved deficits compared with WT mice (Median (interquartile range), $1.75(0.5)$ ) at $24 \mathrm{~h}$ (Figure 7d; $P<0.05$ ). Two WT mice showed stroke-related mortality before $24 \mathrm{~h}$. Inclusion of these mice resulted in a neurological deficit score of 1.5 (1.0) (Median (interquartile range)) in bmf-deficient mice compared with 2.0 (1.63) 
a
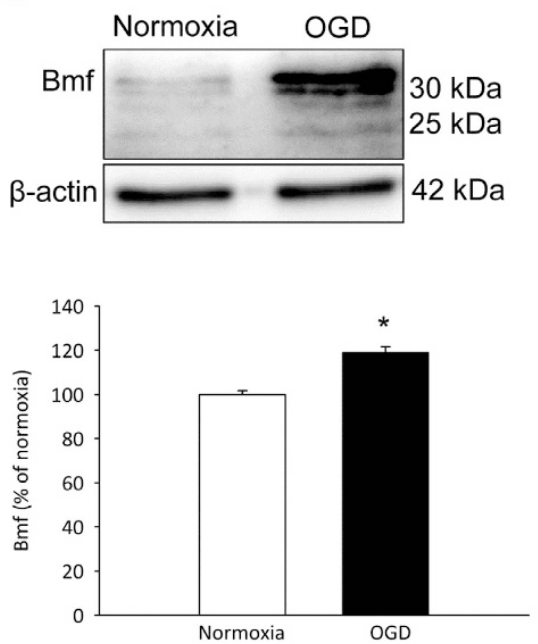

C
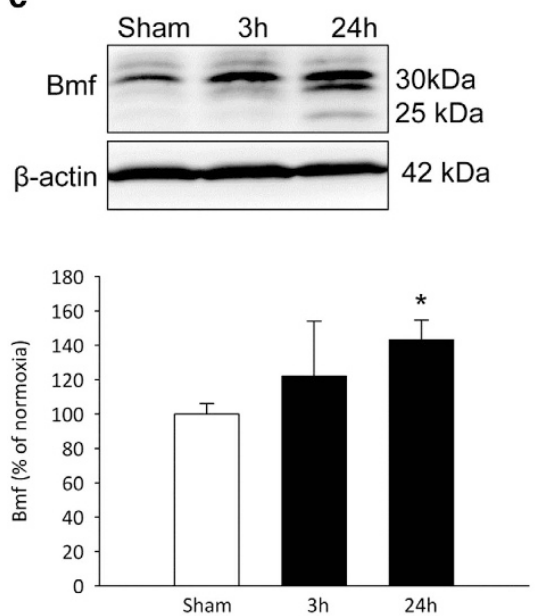

b

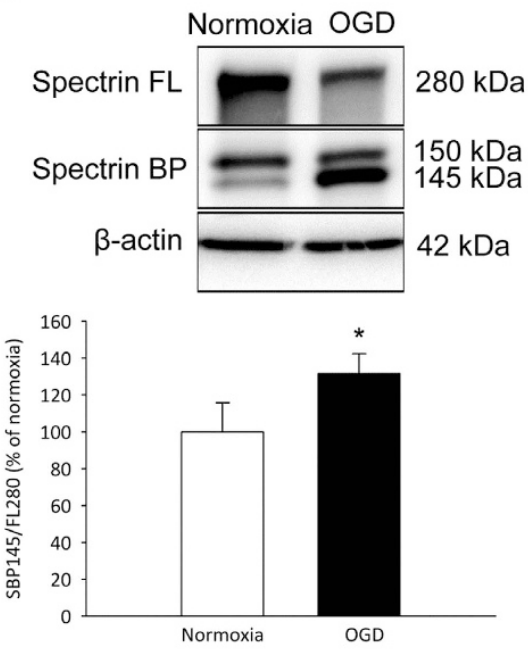

d
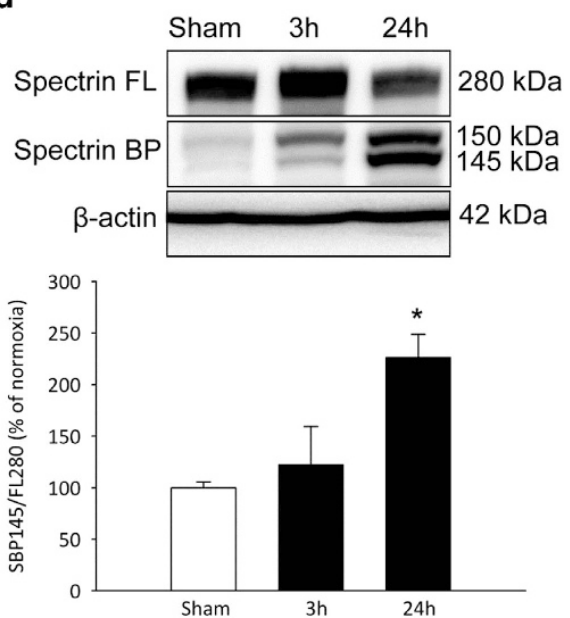

Figure 5 Increased Bmf protein expression following OGD in cortical neurons and transient focal cerebral ischemia in WT mice. (a and b) Western blotting and densitometric analysis comparing the levels of Bmf induction and Spectrin cleavage in cortical neurons, (a) confirming Bmf protein induction at $24 \mathrm{~h}$ and (b) demonstrating an increased accumulation of calpain/caspase-3-generated $\alpha$ ll spectrin breakdown products $(145 / 150 \mathrm{kDa})$ in OGD-treated cultures. Significant increases in Bmf protein induction and Spectrin cleavage were observed at $24 \mathrm{~h}$ compared with sham-treated cultures. Data presented as mean \pm S.E.M. from $n=5$ independent experiments from $n=5$ independent cultures carried out in triplicate. ${ }^{*} P<0.05$ compared with sham-treated controls. (c and $\left.\mathbf{d}\right)$ Western blotting and densitometric analysis comparing levels of Bmf induction and Spectrin cleavage in the ipsilateral cortex 3 and $24 \mathrm{~h}$ following ischemia in WT mice, (c) confirming Bmf protein induction and (d) demonstrating an increased accumulation of $\alpha$ ll spectrin breakdown products at $24 \mathrm{~h}$ reperfusion. Significant increases in Bmf protein induction and Spectrin cleavage were observed at $24 \mathrm{~h}$ compared with matched controls. Densitometry data are expressed as Bmf or as a ratio of the $145 \mathrm{kDa}$ spectrin breakdown product (BP) and the $280 \mathrm{kDa}$ full length (FL) protein normalized to $\beta$-actin. Data presented as mean \pm S.E.M. from $n=4$ per group. ${ }^{*} P<0.05$ compared with matched controls

(Median (interquartile range)) in WT mice, which again was statistically significant (Figure 7e). Collectively, this data indicate that deletion of bmf confers protection against OGD in primary cultured cortical neurons and suggests that bmf may contribute to ischemic neuronal injury and neurological deficit outcome in vivo.

\section{Discussion}

Hypoxic-ischemic brain injury and associated cellular events are worthy of particular investigation as a well-known cause of neuronal cell death and damage. Pathophysiological analysis after focal brain ischemia reveals a necrotic core area of irreversible cell death resulting from total bioenergetic failure due to dramatically reduced metabolic rates of oxygen and glucose. Surrounding this necrotic core lies the ischemic penumbra, an area of less severe damage, functionally impaired but metabolically active tissue, balanced precariously between a complex schism of endogenous neuroprotective and neurotoxic events. ${ }^{1}$ Elucidation of the triggers and mediators of ischemic cell death mechanisms may provide gene-targeted intervention for neuroprotection in stroke, preventing ongoing injury and infarct progression.

To this end, our data from the present study indicate that the pro-apoptotic gene, noxa, although significantly induced, may possibly not become a relevant therapeutic target for the treatment of ischemic stroke. Using gene expression analysis, we observed a robust early induction of noxa mRNA and a corresponding significant induction of Noxa protein levels during OGD in cortical neurons. The transcriptional 

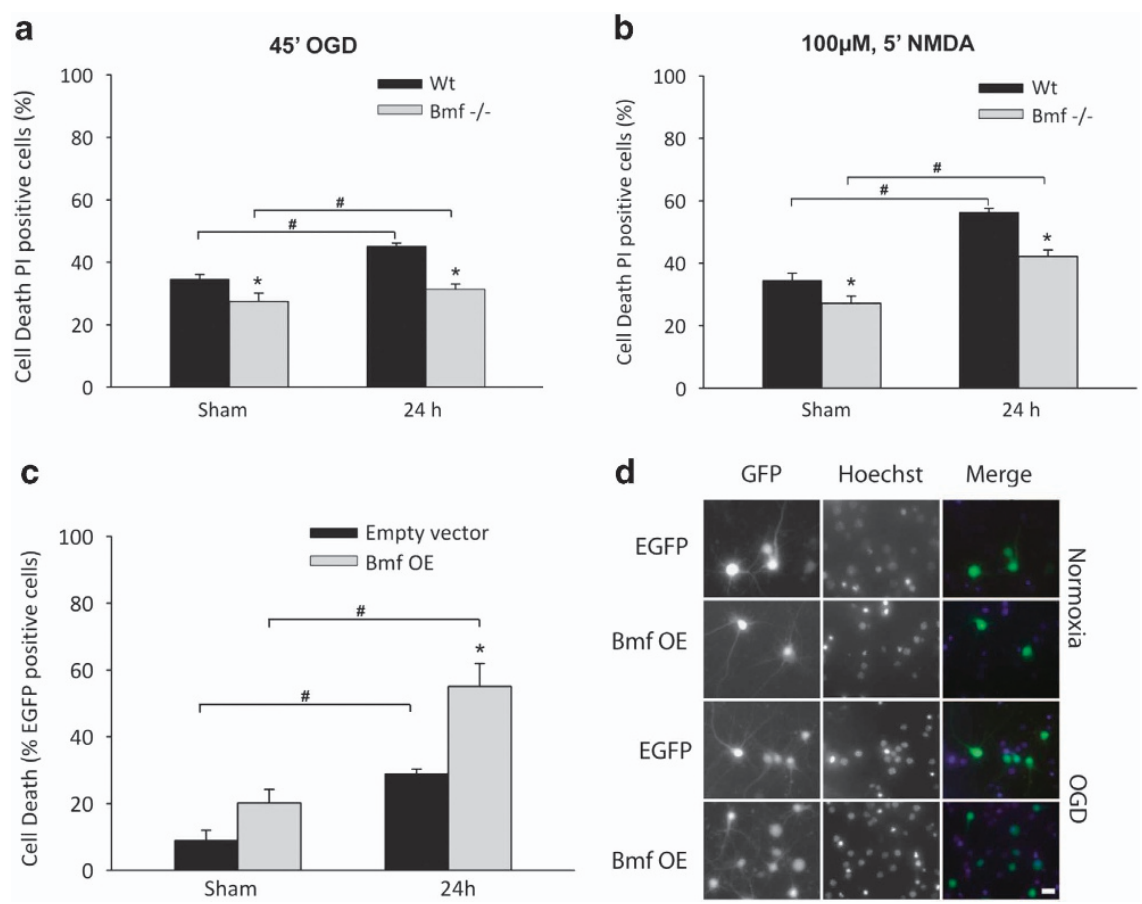

Figure 6 Deletion of bmf confers protection against neuronal injury induced by OGD in cultured primary cortical neurons. Cortical neurons derived from WTand bmf-deficient mice were sham-treated or subjected to either $45 \mathrm{~min} \mathrm{OGD}$ or a model of excitotoxic NMDA receptor overactivation by exposure to NMDA/glycine $(100 \mu \mathrm{M} / 10 \mu \mathrm{M})$ for $5 \mathrm{~min}$ and allowed to recover under normoxic conditions for $24 \mathrm{~h}$. Cell death was assessed $24 \mathrm{~h}$ after OGD or NMDA treatment in each model by Hoechst and PI staining. (a and $\mathbf{b})$ Cell death was significantly reduced in bmf-deficient neurons compared with WT, strongly implicating bmf in the apoptotic response to both (a) OGD and (b) excitotoxic NMDA receptor overactivation. Data presented as mean \pm S.E.M., figures representative of $n=3$ independent experiments from $n=3$ independent cultures carried out in triplicate with similar results. ${ }^{*} P<0.05$ compared with sham-treated control; ${ }^{*} P<0.05$ between treatments (ANOVA, post hoc Tukey's test). (c) Quantification of the effect of Bmf overexpression (OE) in cortical neurons on cell survival after OGD. Neurons were sham-treated or subjected to $45 \mathrm{~min}$ OGD and allowed to recover under normoxic conditions for $24 \mathrm{~h}$. GFP and Hoechst $33358(1 \mu \mathrm{g} / \mathrm{ml})$ fluorescence images were acquired to identify transfected cells and quantify nuclear apoptosis. The number of Hoechst-positive cells with condensed nucleus in eGFP-positive transfected neurons was quantified. Data presented as mean \pm S.E.M. from $n=2$ independent platings carried out in triplicate and pooled. ${ }^{*} P<0.05$ compared with sham-treated control; ${ }^{*} P<0.05$ between treatments. (d) Refpresentative images of Bmf and eGFP co-transfected neurons and control eGFP transfected neurons sham-treated or subjected to $45 \mathrm{~min}$ OGD and allowed to recover under normoxic conditions for $24 \mathrm{~h}$. Scale bar, $10 \mu \mathrm{m}$

upregulation of noxa observed by conditions of OGD in vitro and focal ischemia in vivo is consistent with results reporting induction of noxa during hypoxia and after transient ischemia in vivo by Hif1 $a$ as a mediator of hypoxic cell. ${ }^{25,35}$ Hence the dependence of Noxa induction is not restricted to p53 and associated regulators; ${ }^{27,36}$ noxa transcription and expression can be activated by diverse apoptotic signals in both a p53dependent and independent manner, with numerous regulators and control mechanisms that may be activated to induce noxa at the transcript level, ${ }^{36}$ leading to strong upregulation of noxa mRNA via multiple pathways as observed in our study. Surprisingly, however, our experiments revealed that gene deficiency in noxa did not protect against OGD-induced injury in vitro and that noxa-deficient mice were as susceptible to ischemic damage as WT littermates. Interestingly, Kim et al. .${ }^{35}$ demonstrated a reduction of infarct volume in a rat model of focal ischemia by suppression of noxa expression by antisense oligonucleotides. Disparity in infarct volumes across models may be a result of experimental design and variation ${ }^{42}$ or could be due to species differences. It should also be noted that, despite successful applications of antisense strategies in gene silencing, the use of antisense oligonucleotides as an alternative to gene-knockout models in vivo in practice should be performed with adequate controls to ascertain whether observed physiological effects are the result of an antisense mechanism and not from non-specific effects, such as an intrinsic activity of the phosphorothioate backbone. ${ }^{43}$

Noxa is known to be poorly apoptotic in some cell types, ${ }^{21,36}$ and compared with other BH3-only proteins, Noxa demonstrates tethered potential for neutralization of pro-survival $\mathrm{Bcl}$ 2 proteins, with a more restricted role binding only $\mathrm{Mcl}-1$ and A1. ${ }^{20,21}$ In this context, it is interesting to note that targeting of $\mathrm{Mcl}-1$ by transgenic overexpression of Noxa failed to induce significant cell death in adenovirus oncoprotein E1A immortalized MEFs or NIH3T3 fibroblasts. ${ }^{26}$ Indeed, in a comparison of DNA-damage-induced apoptosis in mice lacking puma and/ or noxa, damage was observed to be cell-type dependent; in mature $\mathrm{CD}^{+}$and $\mathrm{CD}^{+} \mathrm{T}$ cells and macrophages, Puma alone was sufficient to induce apoptosis, while loss of Noxa alone did not notably protect B or $\mathrm{T}$ cells. ${ }^{44}$ Puma was demonstrated to have a major role in most cell types studied, whereas Noxa was only seen to contribute in certain cell types. Contribution of Noxa to cell death may require cell-type dependent engagement of other additional pro-apoptotic factors. Although our analysis has attempted to exclude potentially mitigating factors, cerebrovascular development, subtle anatomical or physiological differences could contribute to our results. However, our data imply that the net effect of noxa is unlikely to contribute significantly to neuronal death signaling after cerebral ischemia. 

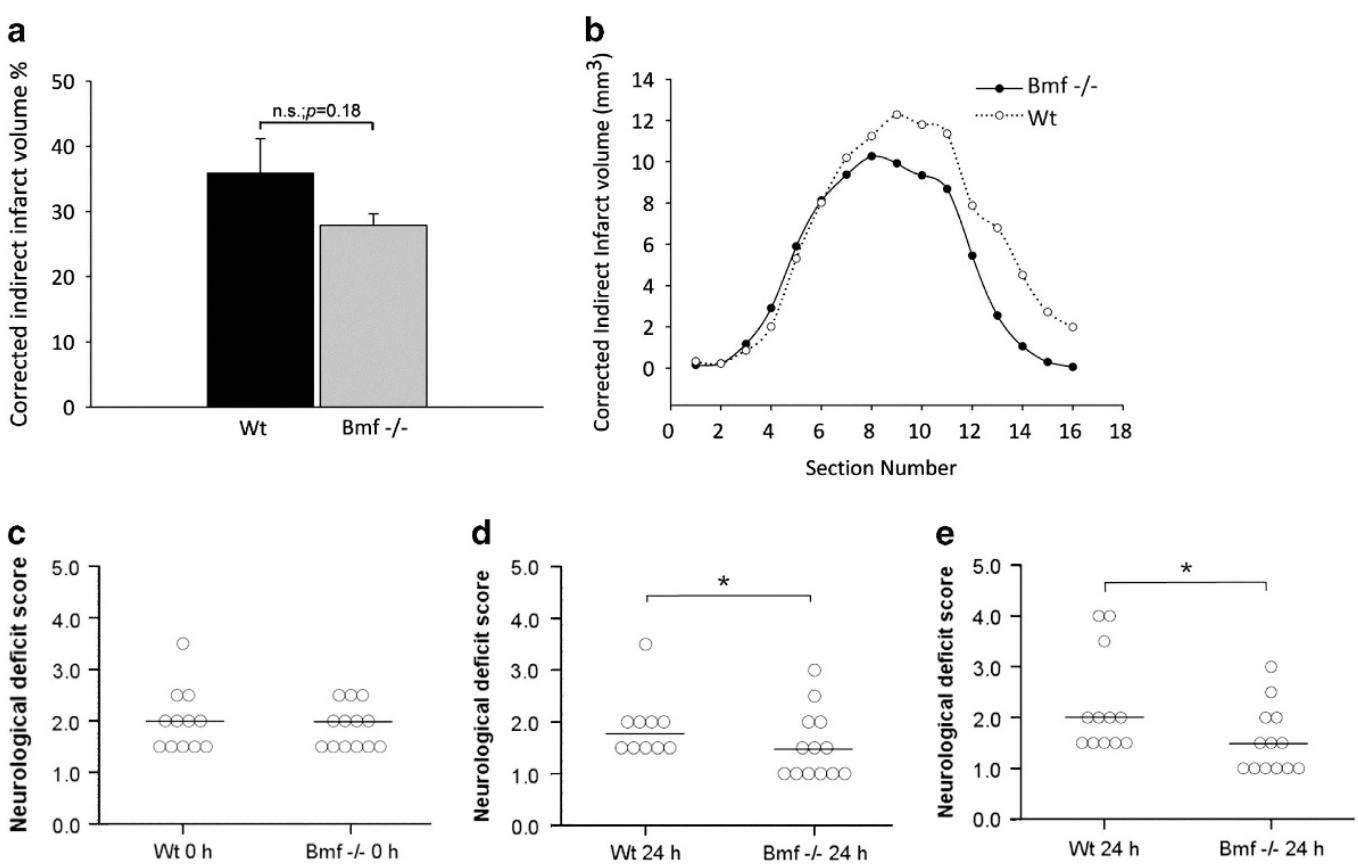

Figure 7 bmf-Deficiency confers protection against ischemic injury. Infarct volume was assessed $24 \mathrm{~h}$ after focal cerebral ischemia by cresyl violet/Nissl staining. Infarct volume was calculated for direct infarct volume and corrected for edema of infarcted tissue for (a) total indirect infarct volume and (b) indirect infarct volume of each section. Lower representation of infarct volume in mice deficient in bmffollowing tMCAO was not found to be significantly reduced when compared with WT mice (Mann-Whitney Utest). Results were quantified and presented as a percentage of infarct volume compared with WT-treated mice. (c and d) Neurological deficit scores after induction of tMCAO in WT and bmfdeficient mice at 0 and $24 \mathrm{~h}$ following $60 \mathrm{~min}$ ischemia with reperfusion. Mice deficient in bmf score were significantly better than WT matched controls after $24 \mathrm{~h}$ reperfusion (Fisher's exact test). (e) Neurological deficit scores at $24 \mathrm{~h}$ following $60 \mathrm{~min}$ ischemia with reperfusion with inclusion of two WT mice that demonstrated stroke-related mortality before $24 \mathrm{~h}$. The bmf- deficient mice maintained a significant reduced deficit compared with WT controls after $24 \mathrm{~h}$ reperfusion. Circles and bar represent deficit score and median score, respectively; ${ }^{*} P<0.05$ compared with WT control. Data are representative of $n \geq 12-13$ for each group of WT and bmf-deficient mice

In contrast to noxa, we did not observe a significant induction of bmf mRNA after OGD or cerebral ischemia. Subsequent experiments revealed a significant induction of Bmf protein levels following OGD in cortical neurons and after ischemic injury in vivo. Of note, experiments performed in primary cortical neurons indicated a significant protection in bmf-deficient neurons both in vitro after OGD- and NMDAinduced excitotoxic injury. In contrast, overexpression of Bmf resulted in significantly exacerbated cell death. bmf deficiency also demonstrated significantly reduced neurological scores after ischemic stroke in an in vivo model of tMCAO in mice. Clearly, it is possible that other BH3-only proteins such as Bid, Bim and Puma may compensate for a bmf-deficiency in vivo. ${ }^{22,23,44,45}$ Of note, bmf mRNA did not appear to be transcriptionally induced early in response to injury. This suggested that bmf contributes to neuronal injury via posttranscriptional activation mechanisms. Bmf is sequestered to the actin cytoskeleton-based myosin V motor complex through its interaction with dynein light chain (DLC)-2 and is released in response to stress stimuli to stimulate apoptosis. ${ }^{28}$ The DLC-binding motif in Bmf closely resembles the region in Bim that mediates its binding to DLC-1, ${ }^{46,47}$ and this interaction with DLC-2 negatively regulates the pro-apoptotic activity of $\mathrm{Bmf}^{28}$ the localization of $\mathrm{Bim}$ and $\mathrm{Bmf}$ to the microtubules and actin cytoskeleton, respectively, may be determined fundamentally by their respective DLC partners. Additionally, Bmf has been shown to be induced posttranscriptionally through enhanced translation under conditions that cause repression of the CAP-dependent translation machinery, including hypoxia. ${ }^{30}$

Several BH3-only proteins, such as Bid, Bim and Bad, 22,48,49 are also constitutively expressed in the brain and rapidly activated in response to focal cerebral ischemia. Collectively, these results suggest that bmf activation may contribute to the development of ischemic neuronal injury; however, there is likely a functional redundancy observable in $\mathrm{BH} 3$-only proteins contributing to ischemic neuronal injury, with similar lack of protection/tendency towards protection observed with deletion of puma in focal cerebral ischemia. ${ }^{24}$ Investigation of ischemic damage in $\mathrm{BH} 3-$ only protein double-knockout models may be valuable to determine whether conductive actions of Noxa or Bmf with other $\mathrm{BH} 3-$ only proteins occur, as reported in other cell death models. ${ }^{50}$

Collectively, the present study not only provides evidence for a role of Bmf as a BH3-only protein contributing to hypoxic/ischemic neuronal injury but also demonstrated that the early induction of noxa did not influence neuronal survival or ischemic injury, suggesting functional redundancy among $\mathrm{BH}$-only proteins for ischemia-induced neuronal death or functions of noxa independent of cell death signaling. These findings are important for future target selection strategies such as neuroprotective interventions to combat ischemic brain injury.

\section{Materials and Methods}

Gene-targeted mice. Animal experiments were carried out under license from the Department of Health and Children (Ireland) and in accordance with European Communities Council Directive (86/609/EEC). All procedures were reviewed and 
approved by local Research Ethics Committee of the Royal College of Surgeons in Ireland. For the analysis of bmf and noxa expression, targeted bmf and noxa mutant mice originally generated from $\mathrm{C} 57 \mathrm{BL} / 6$-derived Bruce4 ES cells backcrossed onto a C57B//6J background were provided by Professor Andreas Strasser (WEHI, Melbourne, Australia) and bred as homozygous knockout colonies. ${ }^{32,51}$ WT C5BI/6J mice were obtained from the Jackson Laboratories (Bar Harbor, ME, USA) and were backcrossed with bmf and noxa WT littermates for $>10$ generations for comparison to bmf and noxa-deficient mice

Genotype analysis. WT and knockout alleles for bmf and noxa were confirmed by PCR analysis of genomic DNA extracted from tail snips using High Pure PCR Template Preparation Kit (Roche, Basel, Switzerland). Genotyping was performed using the specific primers: $5^{\prime}$-GGAGTTCAGACTTCGCCGAGAG-3', 5'-GGCTGGTCACAAAGTTTGACACTG-3' (WT allele-specific); 5'-GGAGTTCAGA CTTCGCCGAGAG-3', and 5'-GCAAGAGGCAAGCCCTTCACTTGG-3' (mutant allele-specific) for bmf, and 5'-GGAGGGCATAAATGGGCAATGACAC-3' (common), 5'-GATGCTTCTTGGGTGCACCCACAC-3' (WT allele-specific reverse), and 5'-AAAGCAATCCCAAACGAC-3' (mutant allele-specific reverse) for noxa.

Preparation of primary mouse neocortical neurons and cell culture. Primary cultures of murine neocortical neurons were prepared and cultured as described previously ${ }^{52}$ with modifications. Briefly, hysterectomies of embryonic day 16-18 pregnant female WT, bmf- and noxa-deficient mice were carried out following cervical dislocation and embryonic cerebral cortices transferred to dissection medium on ice (PBS with $0.25 \%$ glucose and $0.3 \%$ BSA). The tissue was incubated in $0.25 \%$ trypsin-EDTA for $15 \mathrm{~min}$ at $37^{\circ} \mathrm{C}$, and trypsinization was stopped using media containing sera. Neurons were dissociated by gently pipetting and centifugated at $300 \times \mathrm{g}$ for $3 \mathrm{~min}$, and the media containing trypsin was aspirated. Neocortical neurons were triturated in fresh plating medium (MEM containing $5 \%$ fetal bovine serum, $5 \%$ horse serum, $100 \mathrm{U} / \mathrm{ml}$ penicillin/ streptomycin, $0.5 \mathrm{mM}$ L-glutamine and $0.6 \%$ D-glucose). Cells were plated on poly-D-lysine-coated plates at $2 \times 10^{5} \mathrm{cells} / \mathrm{cm}^{2}$ and maintained at $37^{\circ} \mathrm{C}$ and $5 \%$ $\mathrm{CO}_{2}$ humidified atmosphere. After $24 \mathrm{~h}$, medium was exchanged for $1: 1$ plating medium and feeding medium (Neurobasal media containing $100 \mathrm{U} / \mathrm{ml}$ penicillin/ streptomycin, 2\% B27 and $0.5 \mathrm{mM}$ L-glutamine) containing $600 \mathrm{nM}$ cytosine arabinofuranoside. At DIV (days in vitro) 3 , medium containing cytosine arabinofuranoside was exchanged for fresh feeding media. All in vitro experiments were performed on mature cultures at DIV 8-12.

Plasmids and transfection. Primary cortical neurons (DIV 10) were transfected using calcium phosphate. ${ }^{53}$ For overexpression of bmf, cells were transfected with a plasmid encoding murine bmf (generously provided by Professor A Villunger, Innsbruck Medical University, Innsbruck, Austria). ${ }^{30}$ A plasmid with enhanced GFP (eGFP-N1; Clontech, Saint-Germain-en-Laye, France) was used to allow the identification of transfected neurons for cell death assays. Cells were used for experiments $48 \mathrm{~h}$ after transfection.

Oxygen-glucose deprivation. Healthy primary cortical neuron cultures at DIV 8-9 transferred to a hypoxic chamber (COY Lab Products, Grass Lake, MI, USA) with an atmosphere comprising $1.5 \% \mathrm{O}_{2}, 5 \% \mathrm{CO}_{2}$ and $85 \% \mathrm{~N}_{2}$, with temperature maintained at $35^{\circ} \mathrm{C}$. Feeding medium was removed from cultures and replaced with preequilibrated, deoxygenated OGD medium bubbled with $\mathrm{N}_{2}$ for $1 \mathrm{~h}$, consisting of (in mM): $0.3 \mathrm{CaCl}_{2}, 70 \mathrm{NaCl}, 5.25 \mathrm{NaHCO}_{3}, 70 \mathrm{KCl}, 1.25 \mathrm{NaH}_{2} \mathrm{PO}_{4}$, $2 \mathrm{MgSO}_{4}, 10$ sucrose, $\mathrm{pH} \mathrm{6.8}$. After $45 \mathrm{~min}$ of OGD, cultures were returned to oxygenated feeding medium and allowed to recover for $24 \mathrm{~h}$ under normoxic conditions $\left(21 \% \mathrm{O}_{2}\right.$ and $\left.5 \% \mathrm{CO}_{2}\right)$. Sham-treated cultures were transferred to oxygenated glucose-free medium consisting of (in $\mathrm{mM}$ ): $2 \mathrm{CaCl}_{2}, 125 \mathrm{NaCl}, 25$ $\mathrm{NaHCO}_{3}, 2.5 \mathrm{KCl}, 1.25 \mathrm{NaH}_{2} \mathrm{PO}_{4}, 2 \mathrm{MgSO}_{4}$, and 10 sucrose, $\mathrm{pH} 7.5$ and maintained under normoxic conditions $\left(21 \% \mathrm{O}_{2}\right.$ and $\left.5 \% \mathrm{CO}_{2}\right) .{ }^{54}$ Control cultures for protein and gene expression analysis were maintained under normoxic conditions.

NMDA toxicity and determination of neuronal injury. Cortical neurons cultured on 24-well plate for DIV 8-9 were sham-treated or subjected to a model of excitotoxic injury induced by NMDA receptor overactivation ${ }^{37}$ by exposure to NMDA/glycine $(100 \mu \mathrm{M} / 10 \mu \mathrm{M})$ for $5 \mathrm{~min}$ and washed twice in experimental buffer containing (in mM): $120 \mathrm{NaCl}, 3.5 \mathrm{KCl}, 0.4 \mathrm{KH}_{2} \mathrm{PO}_{4}, 20 \mathrm{HEPES}$, $5 \mathrm{NaHCO}_{3}, 1.2 \mathrm{Na}_{2} \mathrm{SO}_{4}, 1.2 \mathrm{CaCl}_{2}$, and 15 glucose, pH 7.4, supplemented with high $\mathrm{Mg}^{2+}(1.2 \mathrm{mM})$.
Neuronal injury resulting from OGD, NMDA excitation or Bmf overexpression was assessed after $24 \mathrm{~h}$ in each model by staining neocortical neurons live with Hoechst 33258 at a final concentration of $1 \mu \mathrm{g} / \mathrm{ml}$ and propidium iodide (PI) (Sigma, St. Louis, MO, USA) dissolved in culture medium after $24 \mathrm{~h}$ for $10 \mathrm{~min}$ at $37^{\circ} \mathrm{C}$. After incubation, nuclear morphology was assessed using an Eclipse TE 300 inverted microscope (Nikon Instruments, Amsterdam, Netherlands) and $\times 20$ NA 0.45 dry objective. Images were taken using a SPOT RT SE CCD camera (SPOT Imaging Solutions, Sterling Heights, MI, USA) and the appropriate filter sets. For each time point and treatment, nuclei uniformly stained with Hoechst were counted as viable and condensed, and PI-positive nuclei were scored as dead neurons and expressed as a percentage of the total population, three subfields captured per well, with a minimum of three wells analyzed per condition. Images were processed using NIH Image $\mathrm{J}$ (Wayne Rasband, National Institute of Health, Bethesda, MD, USA). All scoring was carried out in a blinded manner.

Gene expression analysis using real-time RT-PCR analysis. Total RNA was extracted from primary cortical neurons after OGD treatment in vitro or from murine cerebral cortex 3,8 and $24 \mathrm{~h}$ after 60 min transient MCA occlusion using the RNeasy Mini Kit (Qiagen, Hilden, Germany). First-strand cDNA synthesis was performed using $1 \mu \mathrm{g}$ of total RNA as template and reverse transcribed using Superscript II (Invitrogen, Waltham, MA, USA) primed with $50 \mathrm{pmol}$ random hexamers. Quantitative real-time PCR was performed using the Applied Biosystems 7500 Real-Time PCR System in a MicroAmp optical 96-well reaction plate with optical covers (Applied Biosystems, Waltham, MA, USA) and the QuantiTech SYBR green PCR kit (Qiagen) according to the manufacturer's instruction. Sense and antisense primers used were as follows: $5^{\prime}$-CAACACAAACCCAAGTCCT- $3^{\prime}$ and 5'-CATTTGCAAACACCCTCCTT-3' for bim; 5'-CCCATAAGCCAGGAAGACAA-3' and $5^{\prime}$-CTGAAGCTTTCTGGCGATCT-3' for bmf, 5'-TCAGGAAGATCGGAG ACAAA-3' and 5'-TGAGCACACTCGTCCTTCAA-3' for noxa; $5^{\prime}$-ATGGACTCAGC ATCGGAAGG-3' and $5^{\prime}$-TGGCTCATTTGCTCTTCACG-3' for puma; and $5^{\prime}$-G GGTGTGATGGTGGGAATGG-3' and 5'-GGTTGGCCTTAGGGTTCAGG-3' for $\beta$-actin. The data were analyzed using the Analysis AB 7500 SDS Software (Applied Biosystems), and the generation of specific PCR product was confirmed by melting curve analysis. Data were presented as mean \pm S.E.M.; all samples were normalized to $\beta$-actin levels and expressed as $n$-fold expression relative to matched controls for $n=3$ separate experiments carried out in triplicate.

Protein extraction and western blotting. Tissue and cell pellets were lysed in ice-cold radio immunoprecipitation assay buffer $(25 \mathrm{mM}$ Tris $\mathrm{HCl}, 150 \mathrm{mM}$ $\mathrm{NaCl}, 1 \% \mathrm{NP} 40,1 \%$ sodium deoxycholate and $0.1 \%$ sodium dodecyl sulfate) followed by sonication of tissue on ice. Lysates were centrifuged at $10000 \times \mathrm{g}$ for $10 \mathrm{~min}$ at $4^{\circ} \mathrm{C}$, and supernatants were used for western blotting. Resulting membranes were probed with a mouse monoclonal $\alpha$-fodrin ( $\alpha$ ll-Spectrin) antibody (clone AA6; Millipore, Billerica, MA, USA, 1:1000), rat anti-Bmf monoclonal antibody (a gift from A Villunger, Innsbruck Medical University, Innsbruck, Austria; 1:500), rabbit anti-Noxa polyclonal antibody (ab23563; Abcam, Cambridge, UK, $1: 2000$ ) or a mouse monoclonal anti- $\beta$-actin (Sigma, $1: 5000$ ). Species-specific horseradish peroxidase-conjugated secondary antibodies (Pierce, Rockford, IL, USA, 1:5000) were detected using the Super-Signal West Pico Chemiluminescent Substrate (Pierce) and imaged using a FujiFilm LAS-3000 imaging system (FujiFilm, Sheffield, UK).

Evaluation of PcomA plasticity. Evaluation of the PcomA plasticity was carried out in male WT, bmf- and noxa-deficient mice aged 8-10 weeks $(20-24 \mathrm{~g})$ as described ${ }^{55}$ without ischemia. Briefly, animals were anesthetized with Pentobarbital Sodium (Dolethal; $200 \mathrm{mg} / \mathrm{kg}$ ), and transcardial perfusion fixation was performed with $20 \mathrm{ml} 10 \mathrm{U} / \mathrm{ml}$ heparin in Ringer's solution and $20 \mathrm{ml} 4 \%$ PFA followed by Cresyl Violet $(5 \%, 1 \mathrm{ml})$. The plasticity of the bilateral PcomA was evaluated independently by a blinded investigator (GC) using a dissecting microscope and graded on a qualitative scale of 0-3 as follows: Score 0 , no anastomosis between posterior cerebral artery (PCA) and superior cerebellar artery (SCA); Score 1, anastomosis between PCA and SCA in capillary phase; Score 2, small truncal PcomA; and Score 3, truncal PcomA. Statistical significant differences were analyzed using non-parametric statistics; no significant difference in PcomA plasticity was observed in bmf- or noxa-deficient versus WT control mice, $n>6$ per genotype (Fisher's exact test). The median score of PcomAs were (Median (interquartile range)) $1.0(0.75)$ for noxa-deficient mice, $2.0(0))$ for bmf-deficient mice and $1.0(1.75)$ for WT mice. 
Focal cerebral ischemia model. Induction of transient focal cerebral ischemia was performed in male WT, bmf- and noxa-deficient mice aged $8-10$ weeks $(20-24 \mathrm{~g})$ using the monofilament suture method as described ${ }^{56,57}$ with modifications. Briefly, mice were anesthetized with $5 \%$ isoflurane $30 \% \mathrm{O}_{2}$ and $65 \%$ $\mathrm{N}_{2} \mathrm{O}$ and maintained with $2 \%$ isoflurane, $33 \% \mathrm{O}_{2}$ and $65 \% \mathrm{~N}_{2} \mathrm{O}$ for the duration of surgery $(<20 \mathrm{~min})$. Body temperature was maintained normothermic at $36.8-37.4^{\circ} \mathrm{C}$ via a feedback-controlled heat blanket. A silicon-coated 8-0 nylon monofilament with rounded tip was introduced into the left internal carotid artery and advanced past the carotid artery bifurcation to occlude the MCA. After $60 \mathrm{~min}$, the suture was removed to allow reperfusion. To control for effects of occlusion, sham-treated mice underwent the same surgical procedure, but the filament was not advanced to occlude the vessel. Effective occlusion and assessment of microcirculatory function was monitored by laser-Doppler flowmetry with a probe fixed to the exposed left parietal skull for continuous monitoring of regional cerebral blood flow (Perimed 5001 Master, Perimed, Järfälla, Sweden). Mice were euthanized 3,8 and $24 \mathrm{~h}$ after reperfusion, and the brains were processed either for bmf and noxa expression analysis or for calculation of infarct volume. All surgical procedures were carried out in a blinded manner.

Determination of ischemic infarct volume. Infarct volume was assessed $24 \mathrm{~h}$ after ischemia by a blinded investigator; $10 \mu \mathrm{m}$ coronal sections $(n=16)$ from each brain were cut by Leica CM1950 Cryostat (Leica Biosystems Nussloch $\mathrm{GmbH}$, Heidelberger Str, Germany) and taken at $500 \mu \mathrm{m}$ intervals. Sections were stained with Cresyl violet/Nissl, and infarct area was evaluated quantitatively using an image analysis system by a blinded investigator (Leica Application Suite V3, Germany). Lesion volume was calculated as previously described ${ }^{57}$ by the infarct area multiplied by the section thickness and summed over the entire brain for direct infarct volume and corrected for edema of infarcted tissue for indirect infarct volume. Data are expressed as the percentage of contralateral hemisphere to correct for differences in the brain size and brain edema.

Neurological deficit. Neurological deficit scores were assessed as described previously. ${ }^{22}$ Briefly, the neurological function of mice was evaluated for severity by a blinded investigator (GC) at 0 or $24 \mathrm{~h}$ after ischemia using a five-point scale, as follows: Score 0, no deficit; Score 1, weakness of the contralateral forepaw; Score 2, circling; Score 3, loss of righting reflex; and Score 4, no motor activity. In a separate analysis, stroke-induced death of the animal was scored as 5 .

Statistical analysis. Statistics were carried out on an SPSS-IBM software (IBM, Armonk, NY, USA). mRNA and densitometry data are presented as mean \pm S.E.M. and were analyzed by using one-way ANOVA followed by Tukey's post hoc test to determine statistical significance. $P$-values $<0.05$ were considered to be statistically significant. Infarct volumes were analyzed using non-parametric analyses (Kruskal-Wallis non-parametric analysis, Mann-Whitney U-test); Fisher's exact test was used to compare significant differences in PcomA plasticity and neurological deficit scores. Significance was accepted at $P<0.05$.

\section{Conflict of Interest}

The authors declare no conflict of interest.

Acknowledgements. The authors acknowledge the funding supported by Fundació Científica La Marató TV3 (111630/31) and SFI (08/IN.1/B1949). We wish to thank Professor Andreas Villunger for the generous gifts of the Bmf monoclonal antibody and plasmid; Professor Andreas Strasser and Professor Andreas Villunger for the bmf- and noxa-deficient mice; and Professor Eric Eldering for his help in the shipment of these mice.

1. Dirnagl U, ladecola C, Moskowitz MA. Pathobiology of ischaemic stroke: an integrated view. Trends Neurosci 1999; 22: 391-397.

2. Liou AKF, Clark RS, Henshall DC, Yin XM, Chen J. To die or not to die for neurons in ischemia, traumatic brain injury and epilepsy: a review on the stress-activated signaling pathways and apoptotic pathways. Prog Neurobiol 2003; 69: 103-142.

3. Li J, McCullough LD. Effects of AMP-activated protein kinase in cerebral ischemia. J Cereb Blood Flow Metab 2010; 30: 480-492.

4. Ronnett GV, Ramamurthy S, Kleman AM, Landree LE, Aja S. AMPK in the brain: its roles in energy balance and neuroprotection. J Neurochem 2009; 109(Suppl 1): 17-23.
5. Niizuma K, Yoshioka H, Chen H, Kim GS, Jung JE, Katsu M et al. Mitochondrial and apoptotic neuronal death signaling pathways in cerebral ischemia. Biochim Biophys Acta 2010; 1802: 92-99.

6. Ferrer I, Planas AM. Signaling of cell death and cell survival following focal cerebral ischemia: life and death struggle in the penumbra. J Neuropathol Exp Neurol 2003; 62: 329-339.

7. Cao G, Minami M, Pei W, Yan C, Chen D, O'Horo C et al. Intracellular Bax translocation after transient cerebral ischemia: implications for a role of the mitochondrial apoptotic signaling pathway in ischemic neuronal death. J Cereb Blood Flow Metab 2001; 21: 321-333.

8. Er E, Oliver L, Cartron PF, Juin P, Manon S, Vallette FM. Mitochondria as the target of the pro-apoptotic protein Bax. Biochim Biophys Acta 2006; 1757: 1301-1311.

9. Zhang Y, Cho CH, Atchaneeyasakul LO, McFarland T, Appukuttan B, Stout JT. Activation of the mitochondrial apoptotic pathway in a rat model of central retinal artery occlusion. Invest Ophthalmol Vis Sci 2005; 46: 2133-2139.

10. Linseman DA, Butts BD, Precht TA, Phelps RA, Le SS, Laessig TA et al. Glycogen synthase kinase-3beta phosphorylates Bax and promotes its mitochondrial localization during neuronal apoptosis. J Neurosci 2004; 24: 9993-10002.

11. Hetz C, Vitte PA, Bombrun A, Rostovtseva TK, Montessuit S, Hiver A et al. Bax channel inhibitors prevent mitochondrion-mediated apoptosis and protect neurons in a model of global brain ischemia. J Biol Chem 2005; 280: 42960-42970.

12. Graham SH, Chen J. Programmed cell death in cerebral ischemia. J Cereb Blood Flow Metab 2001; 21: 99-109.

13. Chen J, Graham SH, Chan PH, Lan J, Zhou RL, Simon RP. bcl-2 is expressed in neurons that survive focal ischemia in the rat. Neuroreport 1995; 6: 394-398.

14. Chen J, Graham SH, Nakayama M, Zhu RL, Jin K, Stetler RA et al. Apoptosis repressor genes $\mathrm{Bcl}-2$ and $\mathrm{Bcl}-\mathrm{x}-$ long are expressed in the rat brain following global ischemia. J Cereb Blood Flow Metab 1997; 17: 2-10.

15. Cao G, Pei W, Ge H, Liang Q, Luo Y, Sharp FR et al. In vivo delivery of a Bcl-xL fusion protein containing the TAT protein transduction domain protects against ischemic brain injury and neuronal apoptosis. J Neurosci 2002; 22: 5423-5431.

16. Lawrence MS, Ho DY, Sun GH, Steinberg GK, Sapolsky RM. Overexpression of Bcl-2 with herpes simplex virus vectors protects CNS neurons against neurological insults in vitro and in vivo. J Neurosci 1996; 16: 486-496.

17. Sun $Y$, Jin K, Clark KR, Peel A, Mao XO, Chang $Q$ et al. Adeno-associated virus-mediated delivery of BCL-w gene improves outcome after transient focal cerebral ischemia. Gene Therapy 2003; 10: 115-122.

18. Elmore S. Apoptosis: a review of programmed cell death. Toxicologic Pathol 2007; 35: 495-516.

19. Youle RJ, Strasser A. The BCL-2 protein family: opposing activities that mediate cell death. Nat Rev Mol Cell Biol 2008; 9: 47-59.

20. Kuwana T, Bouchier-Hayes L, Chipuk JE, Bonzon C, Sullivan BA, Green DR et al. BH3 domains of $\mathrm{BH} 3$-only proteins differentially regulate Bax-mediated mitochondrial membrane permeabilization both directly and indirectly. Mol Cell 2005; 17: 525-535.

21. Chen L, Willis SN, Wei A, Smith BJ, Fletcher JI, Hinds MG et al. Differential targeting of prosurvival $\mathrm{Bcl}-2$ proteins by their $\mathrm{BH} 3-$ only ligands allows complementary apoptotic function. Mol Cell 2005; 17: 393-403.

22. Plesnila N, Zinkel S, Le DA, Amin-Hanjani S, Wu Y, Qiu J et al. BID mediates neuronal cell death after oxygen/ glucose deprivation and focal cerebral ischemia. Proc Natl Acad Sci USA 2001; 98: 15318-15323.

23. Yin X. M, Luo Y, Cao G, Bai L, Pei W, Kuharsky DK et al. Bid-mediated mitochondrial pathway is critical to ischemic neuronal apoptosis and focal cerebral ischemia. J Biol Chem 2002; 277: 42074-42081.

24. Kuroki K, Virard I, Concannon CG, Engel T, Woods I, Taki W et al. Effects of transient focal cerebral ischemia in mice deficient in puma. Neurosci Lett 2009; 451: 237-240.

25. Inta I, Paxian S, Maegele I, Zhang W, Pizzi M, Spano P et al. Bim and Noxa are candidates to mediate the deleterious effect of the NF-kappa B subunit RelA in cerebral ischemia. J Neurosci 2006; 26: 12896-12903.

26. Shibue T, Suzuki S, Okamoto H, Yoshida H, Ohba Y, Takaoka A et al. Differential contribution of Puma and Noxa in dual regulation of p53-mediated apoptotic pathways. EMBO J 2006; 25: 4952-4962.

27. Oda E, Ohki R, Murasawa H, Nemoto J, Shibue T, Yamashita T et al. Noxa, a BH3-only member of the Bcl-2 family and candidate mediator of p53-induced apoptosis. Science 2000; 288: 1053-1058.

28. Puthalakath H, Villunger A, O'Reilly LA, Beaumont JG, Coultas L, Cheney RE et al. Bmf: a proapoptotic $\mathrm{BH} 3-$ only protein regulated by interaction with the myosin $\mathrm{V}$ actin motor complex, activated by anoikis. Science 2001; 293: 1829-1832.

29. Hausmann M, Leucht K, Ploner C, Kiessling S, Villunger A, Becker H et al. BCL-2 modifying factor (BMF) is a central regulator of anoikis in human intestinal epithelial cells. J Biol Chem 2011; 286: 26533-26540.

30. Grespi F, Soratroi C, Krumschnabel G, Sohm B, Ploner C, Geley S et al. BH3-only protein Bmf mediates apoptosis upon inhibition of CAP-dependent protein synthesis. Cell Death Differ 2010; 17: 1672-1683.

31. Kilbride S. M, Farrelly AM, Bonner C, Ward MW, Nyhan KC, Concannon CG et al. AMP-activated protein kinase mediates apoptosis in response to bioenergetic stress through activation of the pro-apoptotic Bcl-2 homology domain-3-only protein BMF. J Biol Chem 2010; 285: 36199-36206

32. Labi V, Erlacher M, Kiessling S, Manzl C, Frenzel A, O'Reilly L et al. Loss of the BH3-only protein Bmf impairs $B$ cell homeostasis and accelerates gamma irradiation-induced thymic lymphoma development. J Exp Med 2008; 205: 641-655. 
33. Contreras A. U, Mebratu Y, Delgado M, Montano G, Hu CA, Ryter SW et al. Deacetylation of p53 induces autophagy by suppressing Bmf expression. J Cell Biol 2013; 201: 427-437.

34. Ramirez-Peinado S, Alcázar-Limones F, Lagares-Tena L, El Mjiyad N, Caro-Maldonado A Tirado OM et al. 2-Deoxyglucose induces Noxa-dependent apoptosis in alveolar rhabdomyosarcoma. Cancer Res 2011; 71: 6796-6806.

35. Kim JY, Ahn HJ, Ryu JH, Suk K, Park JH. BH3-only protein Noxa is a mediator of hypoxic cell death induced by hypoxia-inducible factor 1alpha. J Exp Med 2004; 199: 113-124.

36. Ploner $\mathrm{C}$, Kofler R, Villunger A. Noxa: at the tip of the balance between life and death Oncogene 2008; 27(Suppl 1): S84-S92.

37. D'Orsi B, Bonner H, Tuffy LP, Düssmann H, Woods I, Courtney MJ et al. Calpains are downstream effectors of bax-dependent excitotoxic apoptosis. J Neurosci 2012; 32: 1847-1858.

38. Pike BR, Flint J, Dave JR, Lu XC, Wang KK, Tortella FC et al. Accumulation of calpain and caspase-3 proteolytic fragments of brain-derived alphall-spectrin in cerebral spinal fluid afte middle cerebral artery occlusion in rats. J Cereb Blood Flow Metab 2004; 24: 98-106.

39. Newcomb-Fernandez JK, Zhao X, Pike BR, Wang KK, Kampfl A, Beer R et al. Concurrent assessment of calpain and caspase-3 activation after oxygen-glucose deprivation in primary septo-hippocampal cultures. J Cereb Blood Flow Metab 2001; 21: 1281-1294.

40. Morimoto T, Ginsberg MD, Dietrich WD, Zhao W. Hyperthermia enhances spectrin breakdown in transient focal cerebral ischemia. Brain Res 1997; 746: 43-51.

41. Nakajima E, Hammond KB, Rosales JL, Shearer TR, Azuma M. Calpain, not caspase, is the causative protease for hypoxic damage in cultured monkey retinal cells. Invest Ophthalmol Vis Sci 2011; 52: 7059-7067.

42. Carmichael ST. Rodent models of focal stroke: size, mechanism, and purpose. NeuroRx 2005; $2: 396-409$.

43. Dias N, Stein CA. Antisense oligonucleotides: basic concepts and mechanisms. Mol Cancer Ther 2002; 1: 347-355

44. Michalak EM, Villunger A, Adams JM, Strasser A. In several cell types tumour suppressor p53 induces apoptosis largely via Puma but Noxa can contribute. Cell Death Differ 2008; 15 1019-1029.

45. Ness J. M, Harvey CA, Strasser A, Bouillet P, Klocke BJ, Roth KA. Selective involvement of BH3-only Bcl-2 family members Bim and Bad in neonatal hypoxia-ischemia. Brain Res 2006; 1099: $150-159$.

46. Puthalakath $\mathrm{H}$, Huang DC, O'Reilly LA, King SM, Strasser A. The proapoptotic activity of the $\mathrm{Bcl}-2$ family member Bim is regulated by interaction with the dynein motor complex. Mol Cell 1999; 3: 287-296

47. Lo KW, Naisbitt S, Fan JS, Sheng M, Zhang M. The 8-kDa dynein light chain binds to its targets via a conserved (K/R)XTQT motif. J Biol Chem 2001; 276: 14059-14066.

48. Saito A, Hayashi T, Okuno S, Ferrand-Drake M, Chan P. H. Overexpression of copper/zinc superoxide dismutase in transgenic mice protects against neuronal cell death after transient focal ischemia by blocking activation of the Bad cell death signaling pathway. $J$ Neurosci 2003; 23: 1710-1718.
49. Gao Y, Signore AP, Yin W, Cao G, Yin XM, Sun F et al. Neuroprotection against focal ischemic brain injury by inhibition of c-Jun $\mathrm{N}$-terminal kinase and attenuation of the mitochondrial apoptosis-signaling pathway. J Cereb Blood Flow Metab 2005; 25: 694-712.

50. Erlacher M, Labi V, Manzl C, Böck G, Tzankov A, Häcker G et al. Puma cooperates with $\mathrm{Bim}$, the rate-limiting $\mathrm{BH} 3$-only protein in cell death during lymphocyte development, in apoptosis induction. J Exp Med 2006; 203: 2939-2951.

51. Villunger A, Michalak EM, Coultas L, Müllauer F, Böck G, Ausserlechner MJ et al. p53- and drug-induced apoptotic responses mediated by $\mathrm{BH}$-only proteins puma and noxa. Science 2003: 302: 1036-1038.

52. Concannon CG, Tuffy LP, Weisová P, Bonner HP, Dávila D, Bonner $C$ et al. AMP kinasemediated activation of the $\mathrm{BH} 3$-only protein Bim couples energy depletion to stress-induced apoptosis. J Cell Biol 2010; 189: 83-94.

53. Goetze B, Grunewald B, Baldassa S, Kiebler M. Chemically controlled formation of a DNA/ calcium phosphate coprecipitate: application for transfection of mature hippocampal neurons. J Neurobiol 2004; 60: 517-525.

54. Rytter A, Cronberg T, Asztely F, Nemali S, Wieloch T. Mouse hippocampal organotypic tissue cultures exposed to in vitro 'ischemia' show selective and delayed CA1 damage that is aggravated by glucose. J Cereb Blood Flow Metab 2003; 23: 23-33.

55. Murakami K, Kondo T, Kawase M, Chan PH. The development of a new mouse model of global ischemia: focus on the relationships between ischemia duration, anesthesia, cerebral vasculature, and neuronal injury following global ischemia in mice. Brain Res 1998; 780: 304-310.

56. Culmsee C, Zhu C, Landshamer S, Becattini B, Wagner E, Pellecchia M et al. Apoptosisinducing factor triggered by poly(ADP-ribose) polymerase and Bid mediates neuronal cell death after oxygen-glucose deprivation and focal cerebral ischemia. J Neurosci2005; 25: 10262-10272.

57. Plesnila N, Zhu C, Culmsee C, Gröger M, Moskowitz MA, Blomgren K. Nuclear translocation of apoptosis-inducing factor after focal cerebral ischemia. J Cereb Blood Flow Metab 2004; 24: $458-466$

(c) Cell Death and Disease is an open-access journal published by Nature Publishing Group. This work is licensed under a Creative Commons Attribution 4.0 International Licence. The images or other third party material in this article are included in the article's Creative Commons licence, unless indicated otherwise in the credit line; if the material is not included under the Creative Commons licence, users will need to obtain permission from the licence holder to reproduce the material. To view a copy of this licence, visit http://creativecommons.org/licenses/by/4.0 